\title{
Shopping for Health: Whole Grains ${ }^{1}$
}

Wendy J. Dahl and Lauren Foster ${ }^{2}$

\section{Whole grains vs. refined grains}

Grain products include foods such as bread, pasta, breakfast cereals, and crackers. Any food made with wheat, oats, rice, corn, barley, or another cereal is considered a grain product (1).

Whole grains contain the entire grain kernel. Whole-grain foods may be minimally or highly processed.

Refined grains have been processed so that the germ and the bran have been removed (see diagram below). This also removes much of the fiber from the grain. B vitamins, removed in the refining process, need to be added back through enrichment.

\section{How many grains do we need?}

Recommendations for servings of grains depend on your age, gender, and energy needs. The U.S. Department of Agriculture (USDA) recommends that people of all ages get half their grain servings from whole grain sources. An ounce equivalent is comparable to a slice of bread, a cup of breakfast cereal, or a half cup cooked rice or pasta.

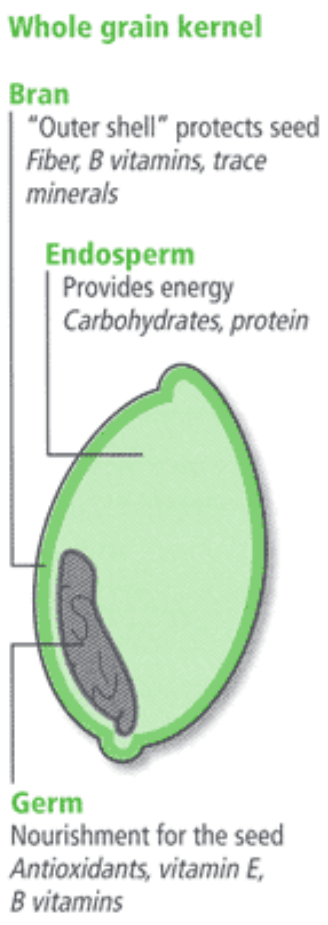

Figure 1. A whole grain kernel consists of three main parts - the fiberrich bran exterior or outer shell, the starchy endosperm it protects, and the nutrient-packed germ, which provides nourishment for the seed. Credits: USDA

1. This document is FSHN10-13/FS161, one of a series of the Food Science and Human Nutrition Department, UF/IFAS Extension. Original publication date November 2010. Revised December 2013. Visit the EDIS website at http://edis.ifas.ufl.edu/.

2. Wendy J. Dahl, PhD, RD, assistant professor, and Lauren Foster, student; Food Science and Human Nutrition Department, UF/IFAS Extension, Gainesville 32611.

The use of trade names in this publication is solely for the purpose of providing specific information. UFखIFAS does not guarantee or warranty the products named, and references to them in this publication does not signify our approval to the exclusion of other products of suitable composition. 
Table 1 lists the recommended daily grain intake for individuals with moderate physical activity (1).

Table 1. Recommended daily grain intake

\begin{tabular}{|l|c|c|}
\hline Life Stage & $\begin{array}{c}\text { Grain } \\
\text { Recommendation } \\
\text { (ounce equivalents/ } \\
\text { day) }\end{array}$ & $\begin{array}{c}\text { Whole Grain } \\
\text { Recommendation } \\
\text { (ounce equivalents/ } \\
\text { day) }\end{array}$ \\
\hline Children, 2-3 & 3 & $1 \frac{1}{2}$ \\
\hline Children, 4-8 & 5 & $2 \frac{1}{2} 2$ \\
\hline Girls, 9-13 & 5 & 3 \\
\hline Girls, 14-18 & 6 & 3 \\
\hline Boys, 9-13 & 6 & 3 \\
\hline Boys, 14-18 & 8 & 4 \\
\hline Women, 19-50 & 6 & 3 \\
\hline Women, 50+ & 5 & 3 \\
\hline Men, 19-30 & 8 & 4 \\
\hline Men, 31-50 & 7 & $3 \frac{1}{2} 2$ \\
\hline Men, 51+ & 6 & 3 \\
\hline
\end{tabular}

\section{Shopping for whole grains}

One of the best ways of identifying foods containing whole grains is to look for a "Whole Grain Stamp"(Figure 2). A "Whole Grain Stamp" on a food package identifies foods approved by the Whole Grains Council.

The ingredient list on the label of food products is also helpful in identifying whole grains. If whole grains are listed as the first ingredient of the product, it is probably a good source of whole grains. Examples of whole grains include: whole wheat, whole oats /oatmeal, whole grain corn, popcorn, brown rice, whole rye and whole grain barley.
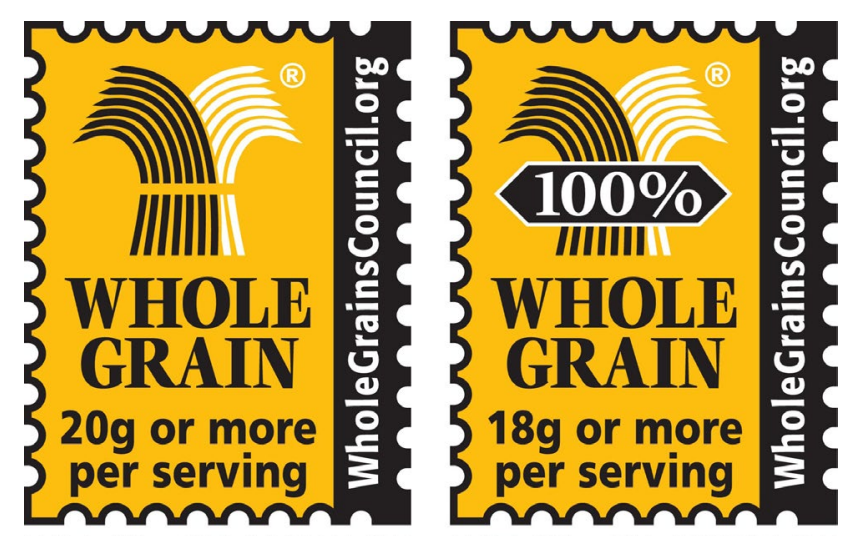

EAT $48 \mathrm{~g}$ OR MORE OF EAT 48g OR MORE OF

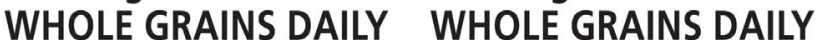

Figure 2. Stamps indicating the minimum grams of whole grains per serving Credits: Whole Grains Council
An example of a whole grain product ingredient list is shown below, taken from Kelloggs Frosted Mini-Wheats cereal.

INGREDIENTS: Whole Grain Wheat, Sugar, High Fructose Corn Syrup, Gelatin, Reduced Iron, Niacinamide, Zinc Oxide....

\section{Shopping for Snacks}

Many whole grain snack foods are becoming available. Whole grains often have more fiber than refined grain snacks which may satisfy your appetite and keep you feeling full longer!

Several brands of crackers and other snack foods offer varieties made with whole grains. Listed below are some snacks that carry the "Whole Grain Stamp". When shopping for snacks, read labels carefully as brands often carry similar varieties that may not have the same quantity of whole grains.

Table 2. Snack foods with whole grains

\begin{tabular}{|c|c|}
\hline Snack & Whole Grains Per Serving (g) \\
\hline Frito-Lay ${ }^{\circledR}$ Sun Chips & 18 \\
\hline Kashi ${ }^{\oplus}$ TLC Crackers & 8 \\
\hline $\begin{array}{l}\text { Rold Gold }{ }^{\circledR} \text { Tiny Twist Pretzels } \\
\text { Made With Whole Grains }\end{array}$ & 8 \\
\hline Cascadian Farm ${ }^{\circledR}$ Granola Bars & 8 \\
\hline Nutri-Grain ${ }^{\circledR}$ Cereal Bars & 8 \\
\hline Tostitos ${ }^{\circledR}$ Tortilla Chips & 8 \\
\hline $\begin{array}{c}\text { General Mills }{ }^{\circledR} \text { Cheerios Snack } \\
\text { Mix }\end{array}$ & 8 \\
\hline \multicolumn{2}{|c|}{$\mathrm{g}=$ gram } \\
\hline
\end{tabular}




\section{Shopping for Dinner}

Shopping for easy-to-cook meals that contain whole grains may seem challenging, but there are several whole grain pastas available in the marketplace, as well as entrées and side dishes that incorporate whole grains. Table 3 lists some examples of entrées and side dishes that contain whole grains.

Table 3. Whole grains for main meals

\begin{tabular}{|c|c|}
\hline Entrée & $\begin{array}{c}\text { Whole Grains } \\
\text { Per Serving } \\
\text { (g) }\end{array}$ \\
\hline Buitoni $^{\circledast} 100 \%$ Whole Wheat Linguini & 62 \\
\hline Buitoni $^{\circledR}$ 100\% Whole Wheat Four Cheese Ravioli & 45 \\
\hline Kashi ${ }^{\circledast}$ Garden Vegetable Pasta & 40 \\
\hline Barilla ${ }^{\circledR}$ Whole Grain Pastas & 28 \\
\hline $\begin{array}{l}\text { Smucker's }{ }^{\circledast} \text { Uncrustables Peanut Butter \& Grape } \\
\text { Jelly on Whole Wheat }\end{array}$ & 16 \\
\hline Kashi® ${ }^{\oplus}$ Frozen Pizzas & 8 \\
\hline Weight Watchers ${ }^{\circledR}$ Pasta with Ricotta \& Spinach & 8 \\
\hline \multicolumn{2}{|l|}{$\mathrm{g}=$ gram } \\
\hline
\end{tabular}

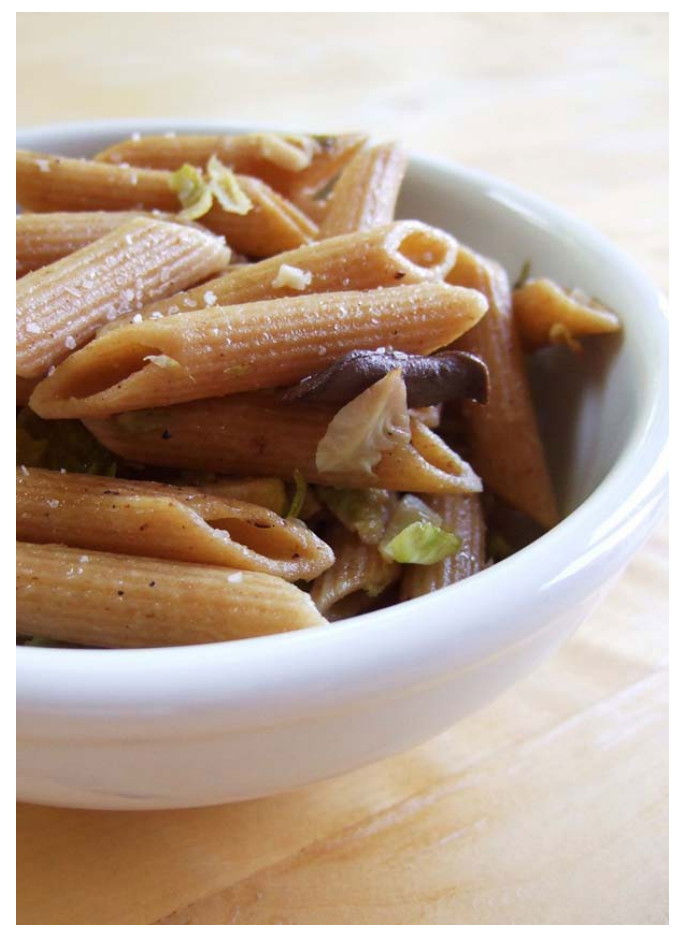

Figure 3. Image of whole wheat pasta with Brussels sprouts and mushrooms. Credits: Photo by Bryan Ochalla and licensed under a Creative Commons Attribution-ShareAlike 2.0 License.

\section{Shopping for Breakfast Cereal}

Getting enough whole grains is becoming easier, as many breakfast cereals are now made with whole grains. Table 4 lists some examples of breakfast cereals that carry the "Whole Grain Stamp". Many more breakfast cereals are made with whole grains, so check the labels of your favorites.

Table 4. Breakfast cereals with whole grains

\begin{tabular}{|c|c|}
\hline Cereal & $\begin{array}{l}\text { Whole Grains } \\
\text { Per Serving (g) }\end{array}$ \\
\hline Kellogg's ${ }^{\circledast}$ Mini-Wheats & 58 \\
\hline Kashi $^{\circledast}$ Summer Berry Granola & 41 \\
\hline Heartland ${ }^{\circledast}$ Granola & 30 \\
\hline Kashi $^{\circledast}$ Go Lean Crunch & 17 \\
\hline Cascadian Farm ${ }^{\circledast}$ Fruit \& Nut Granola & 16 \\
\hline $\begin{array}{c}\text { General Mills }{ }^{\circledR} \text { Cheerios, Multigrain Cheerios, } \\
\text { Total, Wheaties }\end{array}$ & 16 \\
\hline $\begin{array}{c}\text { General Mills }{ }^{\circledR} \text { Cinnamon Toast Crunch, Golden } \\
\text { Grahams, Cocoa Puffs }\end{array}$ & 8 \\
\hline \multicolumn{2}{|l|}{$\mathrm{g}=$ gram } \\
\hline
\end{tabular}

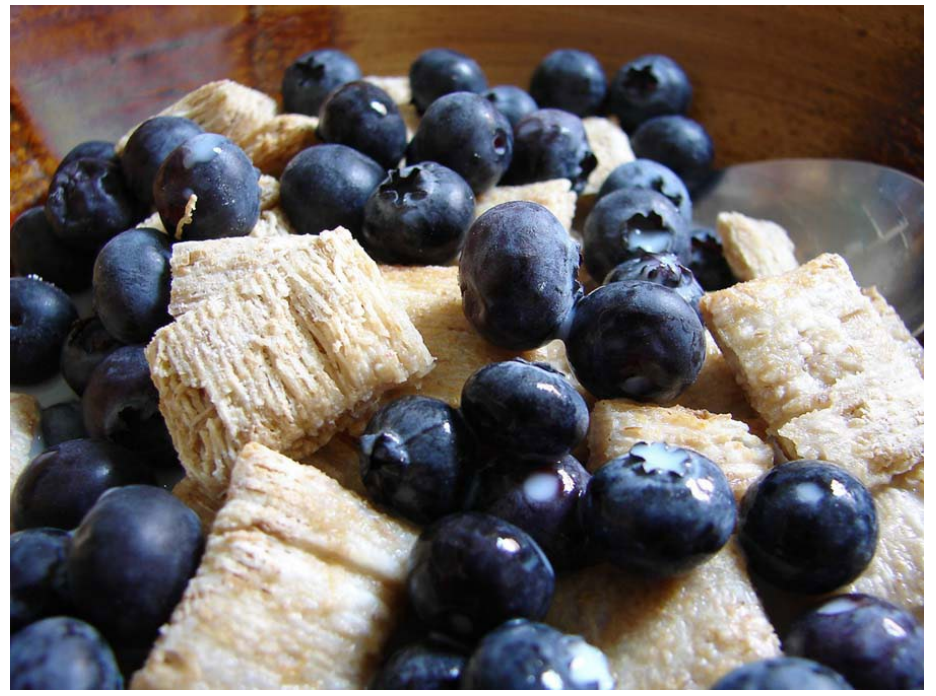

Figure 4. Image of whole grain cereal topped with blueberries. Credits: $\sim$ Photo by Kendalia and licensed under a Creative Commons Attribution-NonCommercial 2.0 License. 


\section{Be an Informed Shopper!}

Substituting whole grain products for refined ones may help with weight management and decrease your risk of chronic diseases (3). When shopping, read food labels and look for the "Whole Grain Stamp"!

Here are tips to help you incorporate whole grains into your day:

- Choose whole grain breads or cereals for breakfast

- Snack on whole wheat pita triangles and hummus

- Snack on whole grain ready-to-eat cereals

- Serve brown rice instead of white

- Substitute whole wheat flour for all-purpose flour in baking

\section{References}

1.U.S. Department of Agriculture. MyPlate. Accessed: 21 December 2013. . http://www.choosemyplate.gov/foodgroups/grains.html

2. Whole Grains Council. Whole Grain Stamp. Accessed: 21 December 2013. http://wholegrainscouncil.org/ whole-grain-stamp

3. U.S. Department of Health and Human Services and U.S. Department of Agriculture. Dietary Guidelines for Americans, 2010. 7th Edition, Washington, DC: U.S. Government Printing Office, January 2010. 